\title{
Metalloproteomics Approach to Analyze Mercury in Breast Milk and Hair Samples of Lactating Women in Communities of the Amazon Basin, Brazil
}

\author{
M. R. Cerbino ${ }^{1}$ José Cavalcante Souza Vieira ${ }^{2}$ - C. P. Braga ${ }^{2}$. G. Oliveira ${ }^{2}$ • \\ I. F. Padilha ${ }^{3}$ - T. M. Silva ${ }^{4}$ L. F. Zara ${ }^{4}$ - N. J. Silva Jr. ${ }^{1}$ P. M. Padilha ${ }^{2}$
}

Received: 24 November 2016 / Accepted: 16 May 2017 / Published online: 25 May 2017

(C) Springer Science+Business Media New York 2017

\begin{abstract}
Mercury is a potentially toxic element that is present in the environment of the Brazilian Amazon and is responsible for adverse health effects in humans. This study sought to assess possible protein biomarkers of mercury exposure in breast milk samples from lactating women in the Madeira and Negro Rivers in the Brazilian Amazon. The mercury content of hair samples of lactating women was determined, and the proteome of breast milk samples was obtained using twodimensional electrophoresis after protein precipitation with acetone. Mercury measurements of protein spots obtained via protein fractionation were performed by graphite furnace atomic absorption spectrometry (GFAAS), and it was observed that mercury is linked to proteins with molecular masses in the range of 14-26 kDa. The total mercury concentration was also determined by GFAAS in unprocessed milk, lyophilized milk, and protein pellets, with the purpose of determining the mercury mass balance in relation to the concentration of this element in milk and pellets. Approximately 85 to $97 \%$ of mercury present in the lyophilized milk from samples of lactating women of the Madeira River is bound in the
\end{abstract}

Electronic supplementary material The online version of this article (doi:10.1007/s12011-017-1057-4) contains supplementary material, which is available to authorized users.

José Cavalcante Souza Vieira

jcavalcante@ibb.unesp.br

1 Pontifical Catholic University of Goiás (PUC), Goiânia, GO, Brazil

2 Institute of Biosciences, São Paulo State University (UNESP), Botucatu, Brazil

3 São Paulo State University (UNESP), São José do Rio Preto, SP, Brazil

4 College of Planaltina, University of Brasília (UnB), Brasília, Federal District, Brazil protein fraction. From lactating women of the Negro River, approximately $49 \%$ of the total mercury is bound in the protein fraction, and a difference of $51 \%$ is bound in the lipid fraction.

Keywords Mercury in milk - Biomarkers of mercury exposure $\cdot$ Metallomics study $\cdot$ 2D-PAGE $\cdot$ GFAAS

\section{Introduction}

The occupation policy of the Brazilian Amazon started in the 1970s and was marked by large-scale deforestation. Forest degradation and destruction for mining, agricultural activities, timber extraction, road and dam construction, and the largescale exploitation of natural resources entailed serious environmental imbalances. Generally, such environmental degradation can result in the remobilization of toxic substances into the environment, potentially contaminating biota and humans [1].

It estimated that approximately 3000 tons of mercury was released in the middle of the Amazon environment, principally in the 1970s and 1980s. However, studies performed in distant areas and without gold mining activity registrations in the high Negro River reveal elevated mercury concentrations, which indicates the possibility of naturally occurring mercury sources. It is also suggested that burning and deforestation would allow long-term atmospheric mercury deposited on soils to run off into rivers, explaining the high mercury concentrations in areas without a gold mining history. However, according to some researchers, Amazonian soils are naturally high in mercury $(\mathrm{Hg})$, which naturally ends up in the aquatic systems $[2,3]$.

Mercury is a ubiquitous element which occurs naturally in the earth's crust, making it a global pollutant [4]. As mercury 
is potentially toxic, it can be responsible for serious poisoning in humans. Depending on its chemical form, it can cause adverse health effects and even irreversible damage to the urinary system, respiratory system, immunological system, reproductive system, and central nervous system $[5,6]$. During biogeochemical mercury cycling by aquatic microorganisms, mercury tends to be bioaccumulated along the trophic chain. Several studies indicate high mercury concentrations in Amazonian fish species, which are the main food source for riverine human communities in this region [7].

Young children are particularly vulnerable to environmental toxicants. They take up high amounts of these substances through their gastrointestinal tracts, their brains are at early developmental stages, and their metabolic pathways are immature and can be easily disturbed by toxic elements such as mercury. Other factors, such as low body mass and high food and water uptake in relation to body mass, may also increase susceptibility to environmental toxicants $[8,9]$. Exposure of both men and women to toxical metals during the reproductive ages, even in relatively small doses, can have impacts on fetal growth and development. During pregnancy, mercury easily crosses the placenta and the blood-brain barrier and reaches the fetal brain, resulting in low birth weight and affecting cognitive development. Early exposure to mercury has been related to neuropathology and the development of CNS. It can also result in speech and mobility delays, altered reflex and muscle tone and, in severe cases, symptoms similar to those of cerebral palsy $[10,11]$.

Human breast milk can contain toxic metals, including mercury, depending on the exposure of the mother. Thus, infants may be subjected to deleterious and neurotoxic effects of mercury, including severe brain damage $[8,12,13]$. Studies on the toxicodynamics of mercury are therefore of fundamental importance for the health of human populations in the Amazon region. Organic and inorganic forms of mercury have been detected in human milk, making breast-feeding a transport mechanism for $\mathrm{Hg}$ from the mother to the newborn [14, $15]$.

In this context, the study of metals in biological systems can help to identify potential biomarkers for metalloproteins associated with mercury, indicating possible contamination risks [16]. Considered emerging research fields, metallomics and proteomics can combine to characterize the proteome and metallome to allow a deeper understanding and wider balance of the use and functions of metals, essential or not, in cells and biological systems. The metalloproteomic approach has become a valuable tool to access information about the metal exposure of various organisms; although it can provide information about the interactions and transport of metals, it is still a relatively unexplored field $[16,17]$.

Therefore, the present study aimed to identify possible biomarkers of exposure to mercury through metalloproteomic studies of breast milk samples from lactating women in
Amazonian communities along the Madeira River and the Negro River, Brazil.

\section{Experimental}

\section{Sampling Sites}

Hair and breast milk samples were collected in the Madeira River communities Fortress Abunã, Abuna, and Nova Mutum Paraná, within the UHE Jirau reservoir in the state of Rondônia, and in the Upper Negro River communities Livramento and Santa Isabel, both in the state of Amazonas (Fig. 1).

\section{Collection of Biological Samples}

A total of 28 lactating women participated, divided into three groups, and participated in this study (Table 1). Prior to the collection of hair and breast milk samples, all mothers who agreed to participate in the study were subjected to a counseling interview and signed a consent form. The project was approved by the Ethics Committee of the Faculty of Medicine of the University of Brasilia (UnB).

\section{Collection and Processing of Hair Samples}

Hair samples were collected to confirm the presence of mercury in infants and to identify individuals with higher levels of contamination. The samples were collected according to international protocols; in brief, $5 \mathrm{~g}$ of hair was collected from the neck region with stainless steel scissors. The samples were placed in polyethylene bags, labeled, and stored in an appropriate place until analysis.

The hair samples were cut with scissors into pieces of approximately $5 \mathrm{~mm}$ in length. Next, the samples were rinsed in a beaker containing acetone p.a. and stirred with a glass rod for $10 \mathrm{~min}$. The sample was then decanted, the supernatant containing acetone was discarded, and ultrapure water was added to the beaker (at the same volume as the acetone) followed by stirring for $10 \mathrm{~min}$. Finally, the sample was decanted again and the water was discarded; this procedure was repeated three times. After the washings, the sample was transferred to a clean container and completely dried at room temperature [18].

\section{Collection and Processing of Breast Milk Samples}

Breast milk was collected in sterilized glass bottles via manual expression. Immediately after collection, samples were labeled, frozen, and sent to the Analytical Chemistry Laboratory and Electrophoresis of UNESP in Botucatu SP, where they were stored at $-20^{\circ} \mathrm{C}$ until analysis. 


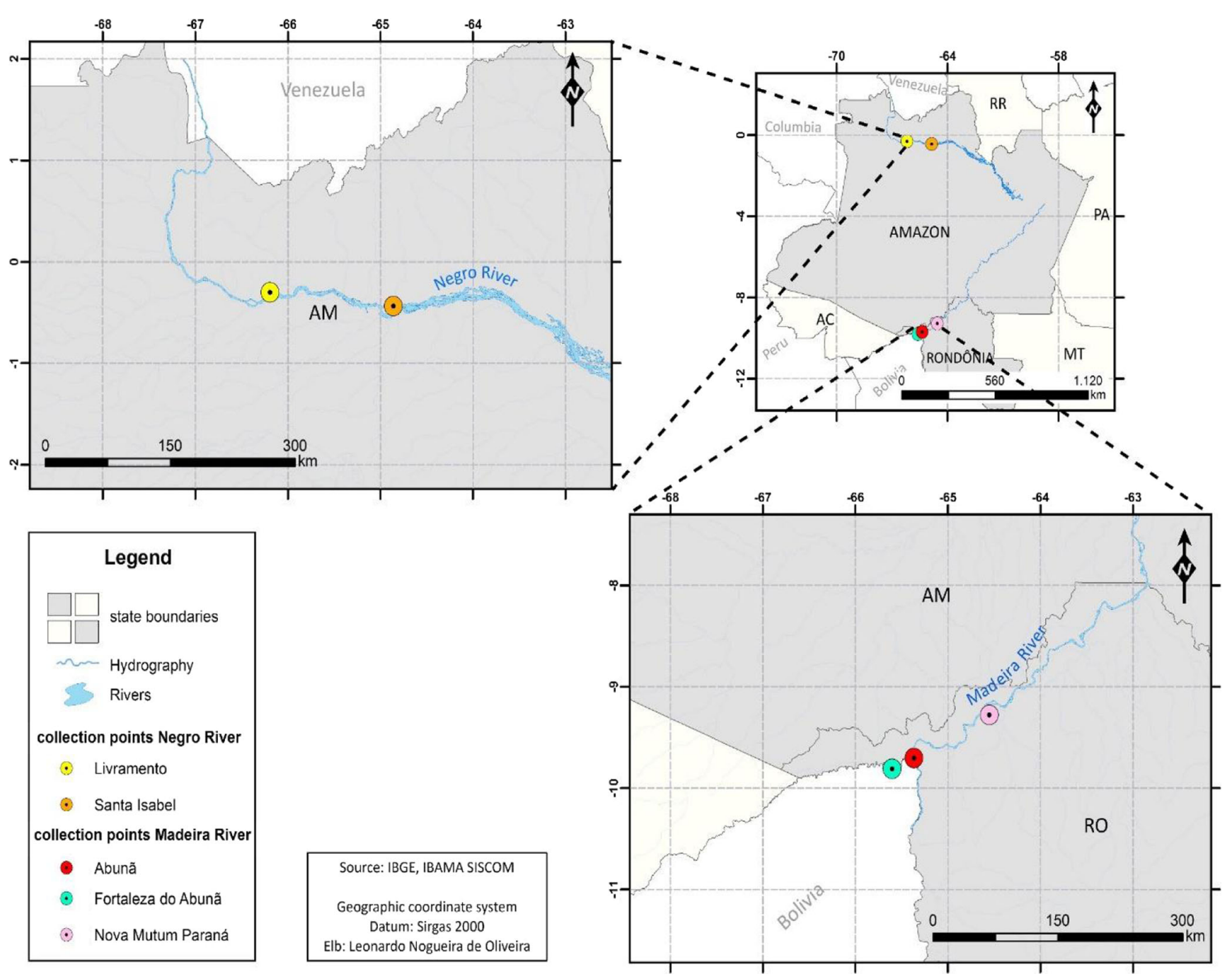

Fig. 1 Sampling sites for hair and breast milk samples

Prior to analysis, the samples were thawed at room temperature and centrifuged six times in a refrigerated centrifuge at $14,000 \mathrm{rpm}$ and $4{ }^{\circ} \mathrm{C}$ for $15 \mathrm{~min}$ to separate the lipid fraction (which accounts for approximately $60 \%$ of the sample) from the protein fraction [19]. To obtain protein pellets, $400 \mu \mathrm{L}$ of

Table 1 Location of communities and distribution of lactating women.

\begin{tabular}{llll}
\hline Communities & Lactating & Regions & Groups \\
\hline${ }^{\mathrm{a}}$ Fortaleza do Abunã & 1 & Madeira River & 1 \\
${ }^{\mathrm{a}}$ Abunã & 4 & Madeira River & 1 \\
${ }^{\mathrm{a}}$ Nova Mutum Paraná & 2 & Madeira River & 1 \\
${ }^{\mathrm{b}}$ Livramento & 12 & Negro River & 2 \\
${ }^{\mathrm{b}}$ Santa Isabel & 6 & Negro River & 2 \\
${ }^{\mathrm{c}}$ Goiânia & 3 & Goiania & 3 \\
\hline
\end{tabular}

${ }^{\mathrm{a}}$ Communities located on the banks from the Madeira River

${ }^{\mathrm{b}}$ Communities located on the banks from the Negro River

${ }^{\mathrm{c}}$ Control group-lactating from the city of Goiania (capital of Goias state) that affirmed to consume a diet based on chicken meat the protein fraction was mixed with $1600 \mu \mathrm{L}$ of $80 \%$ acetone (1:4 ratio) and the mixture was kept in a freezer for $3 \mathrm{~h}$. The tubes containing extract and acetone were then centrifuged for $15 \mathrm{~min}$ at $4{ }^{\circ} \mathrm{C}$ and $13,000 \mathrm{rpm}$. The obtained pellets were washed with acetone and used for the quantification of proteins and total mercury and for the electrophoretic runs (2DPAGE).

\section{Determination of Total Mercury in Hair Samples}

To determine the total Hg levels, an automatic mercury analyzer that employs thermal decomposition and gold amalgamation (SMS 100 Mercury Analyzer; Perkin Elmer, Waltham, Massachusetts, USA) was used. After washing, the hair samples were weighed in a "boat" composed of nickel and subsequently subjected to mercury analysis via combustion (thermal decomposition) with oxygen. During this process, gases are carried through a heated catalytic tube where halogens, nitrogen oxides, and sulfur oxides are removed. The 
remaining decomposition products are then carried to an amalgamator containing gold sand that captures the elemental $\mathrm{Hg}$ $\left(\mathrm{Hg}^{0}\right)$. Subsequently, the amalgamator is heated and releases $\mathrm{Hg}$ vapor, which is transported via a carrier gas into a cold vapor atomic absorption spectrometer. The transient signal is measured in series by a high-sensitivity cell followed by a low-sensitivity cell. At the end of this analysis, there was no residue from the analyzed hair in the "boat" [18].

\section{Precipitation Strategies of Proteins in Breast Milk Samples}

One portion of the protein pellets obtained from breast milk samples was re-solubilized in $0.50 \mathrm{~mol} \mathrm{~L}^{-1} \mathrm{NaOH}$ for quantification of total protein. Another portion was re-solubilized in a specific buffer containing $7 \mathrm{~mol} \mathrm{~L}^{-1}$ urea, $2 \mathrm{~mol} \mathrm{~L}^{-1}$ thiourea, $2 \%$ CHAPS $(\mathrm{m} / \mathrm{v})$, and $10 \%$ ampholyte with $\mathrm{pH}$ range of 3 to 10 and $0.002 \%$ bromophenol blue. Furthermore, $2.8 \mathrm{mg}$ of DTT was added. This solution was used in electrophoretic separations to obtain the proteome of the breast milk samples.

\section{Determination of Total Protein}

The total protein in the protein pellets was determined according to the Biuret method, using bovine serum albumin as the standard [20]. An analytical curve was constructed with concentrations of 5 to $50 \mathrm{~g} \mathrm{~L}^{-1}$ from a stock standard solution of bovine albumin $\left(100 \mathrm{~g} \mathrm{~L}^{-1}\right)$. The protein precipitates were then re-solubilized in $500 \mu \mathrm{L}$ of $0.50 \mathrm{~mol} \mathrm{~L}^{-1} \mathrm{NaOH}$ in glass cuvettes with $50 \mu \mathrm{L}$ standard/sample and $2.5 \mathrm{~mL}$ of biuret reagent. The samples were kept at $32{ }^{\circ} \mathrm{C}$ in a water bath for $15 \mathrm{~min}$; subsequently, their absorbance was measured at $545 \mathrm{~nm}$ using a spectrophotometer in the visible-UV range. The determination of total protein was performed by calculating the exact amount of protein extract needed to yield a mass of $375 \mu \mathrm{g}$ of protein in each sample for the first stage of twodimensional electrophoresis.

\section{Protein Fractionation by Two-Dimensional Electrophoresis (2D-PAGE)}

The process of protein fractionation to obtain the proteome of the breast milk samples was carried out by two-dimensional electrophoresis (2D-PAGE) using procedures described by Santos et al. 2015 and Pozzi et al. 2015 [18, 19]. The separation programs for the first dimension (isoelectric focusingIEF) and second dimension (SDS-PAGE) lasted 4.5 and $5.5 \mathrm{~h}$, respectively.

After the SDS-PAGE (second dimension of electrophoretic separation), the proteins were revealed by the colorant colloidal Coomassie, which is a solution of $8 \%$ ammonium sulfate $(w / v), 1.6 \%$ phosphoric acid $(v / v), 0.08 \%$ Coomassie blue G-250 $(w / v)$, and $25 \%$ methanol $(v / v)$. Prior to staining, the proteins were fixed for $1 \mathrm{~h}$, using a solution containing $10 \%$ acetic acid $(v / v)$ and $40 \%$ ethanol $(v / v)$. The dye was kept in contact with the gel for $72 \mathrm{~h}$ and was then removed by successive rinses with deionized water. The gels obtained, in triplicate, were scanned using a GE Healthcare scanner. Scanned images were analyzed to evaluate the correlation between gel repetitions as well as the count of "spots" (protein) therein, using the ImageMaster Platinum program [21-23].

\section{Determination of Total Mercury in the Breast Milk Samples, Pellets, and Protein Spots}

Briefly, approximately $50 \mathrm{mg}$ of pellets and/or $250 \mu \mathrm{L}$ (measured in triplicate) of breast milk and/or six protein spots cut from polyacrylamide gels were transferred to $5 \mathrm{~mL}$ digestion tubes. To each digestion tube were transferred $1.00 \mathrm{~mL}$ of concentrated sulfuric acid and $0.25 \mathrm{~mL}$ of $30 \%$ hydrogen peroxide $(\mathrm{m} / \mathrm{m})$. The assembly of digestion tubes was placed in the digester block with warming until complete mineralization of the sample was achieved (clear extract after heating at $80^{\circ} \mathrm{C}$ for around two hours). Then, the acid extracts were transferred to $5 \mathrm{~mL}$ volumetric flasks and filled to volume with ultrapure water $\left(18.2{\left.\mathrm{M} \Omega \mathrm{cm}^{-1}\right)}^{2}[18]\right.$. The certificate standard of muscle protein DORM 4-NRC containing $410 \pm 55 \mu \mathrm{g} \mathrm{kg}^{-1}$ and certificate standard of liver protein DOLT 4-NRC containing $2.580 \pm 220 \mu \mathrm{g} \mathrm{kg}^{-1}$ of total mercury were used to validate the mineralization method. These standard reference materials were used because they present a fat and protein content close to the matrix of breast milk.

The concentrations of total mercury in the acid extracts of breast milk samples, pellets and protein spots were determined by graphite furnace atomic absorption spectrometry (GFAAS) $[18,23-26]$. For this, an analytical curve was prepared with Titrisol Merck ${ }^{\circledR}$ mercury aqueous standard solutions in the concentration range of 0.10 to $2.00 \mu \mathrm{g} \mathrm{L}^{-1}$, and the absorbance values of standard solutions and samples were measured with a Shimadzu atomic absorption spectrometer model AA-6800. This spectrometer is equipped with a background absorption broker with a deuterium lamp and a self-reverse system (SR) as well as a pyrolytic graphite tube with an integrated platform and autosampler ASC-6100. A hollow cathode lamp mercury Shimadzu was operated with a minimum current of $12 \mathrm{~mA}$ and a maximum current of $400 \mathrm{~mA}$ (current used in background correction - BG). The wavelength used was $253.7 \mathrm{~nm}$, with $0.5 \mathrm{~nm}$ spectral resolution. Argon was used as the inert gas, maintaining a constant flow of $1 \mathrm{~L} \mathrm{~min}^{-1}$ during the heating program, except for the atomization step, in which the gas flow was stopped. Absorbance signals were measured by their peak areas for better repeatability. The inner walls of the graphite tubes with integrated platforms used for mercury analysis were coated with tungsten. In the pipe coating process, aliquots of $25 \mu \mathrm{L}$ of $1.000 \mathrm{mg} \mathrm{L}^{-1}$ sodium tungstate solution modifier were 
injected into the atomizer, which was then subjected to the program described by Silva et al. (2007) [25]. After this treatment, the average life of the tube was 690 firings.

\section{Results and Discussion}

\section{Total Mercury in Hair Samples}

Hair is a well-established matrix in the study of toxic metals and considered a good bioindicator of mercury contamination [18]. Figure 2 shows the total mercury concentrations of hair samples of all 27 participants, with a mean of $4.49 \pm 5.99 \mu \mathrm{g} \mathrm{g}^{-1}$ and a range from 0.13 to $20.48 \mu \mathrm{g} \mathrm{g}^{-1}$. It is observed that only the value referring to breast milk samples M01 is below the limit of quantification of the method of analysis (LOQ). The LOQ calculated for the method, according to the procedure described by Santos et al. (2015), was $0.10 \mathrm{ng} \mathrm{g}^{-1}[18]$. Table 2 shows the total mercury concentrations of hair samples of participants in each region.

In lactating women of the Madeira River, the mean mercury concentration was $1.07 \pm 0.64 \mu \mathrm{g} \mathrm{g}^{-1}$, ranging between

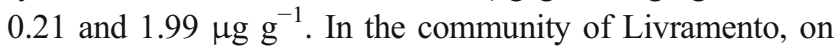
the Negro River, the mean mercury concentration was $2.12 \pm 1.72 \mu \mathrm{g} \mathrm{g}^{-1}$, ranging from 0.33 to $6.53 \mu \mathrm{g} \mathrm{g}^{-1}$. The fish consumption of the coastal communities of the Negro River is higher than that of the communities of the Madeira River, according to the questionnaire answered by lactating women of both communities. This information explains the highest concentrations of mercury found in lactating women in the Negro River. In the upper Negro River, in the community of Santa Isabel, the mean total mercury concentration was $14.62 \pm 4.44 \mu \mathrm{g} \mathrm{g}^{-1}$, ranging between 8.81 and $20.48 \mu \mathrm{g} \mathrm{g}^{-1}$. These values are above $6-8 \mu \mathrm{g} \mathrm{Hg}$ per gram of hair, a

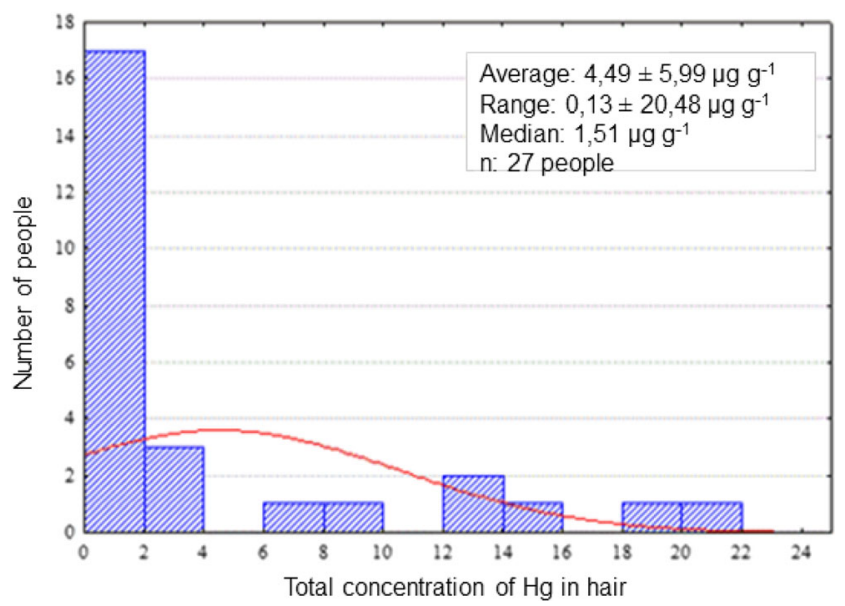

Fig. 2 Distribution of total mercury concentrations $\left(\mu \mathrm{g} \mathrm{g}^{-1}\right)$ in hair samples from lactating women of the study communities (Madeira River, Negro River, and Goiania)
Table 2 Total mercury concentrations in lactating women's hair samples from communities of the Madeira River and Negro River

\begin{tabular}{lll}
\hline Communities & Lactating & $\begin{array}{l}\text { Mercury total } \\
\left(\mu \mathrm{g} \mathrm{g}^{-1}\right)\end{array}$ \\
\hline Nova Mutum & M 01 \\
Nova Mutum & M 02 & a \\
Abunã & M 03 & 0.21 \\
Abunã & M 04 & 1.60 \\
Abunã & M 05 & 0.91 \\
Abunã & M 06 & 0.64 \\
Fortaleza do Abunã & M 07 & 1.99 \\
Livramento & LIV 01 & 1.51 \\
Livramento & LIV 02 & 0.89 \\
Livramento & LIV 03 & 3.04 \\
Livramento & LIV 04 & 1.22 \\
Livramento & LIV 05 & 3.82 \\
Livramento & LIV 06 & 1.08 \\
Livramento & LIV 07 & 0.33 \\
Livramento & LIV 08 & 1.22 \\
Livramento & LIV 09 & 1.37 \\
Livramento & LIV 10 & 6.53 \\
Livramento & LIV 11 & 1.32 \\
Livramento & LIV 12 & 2.81 \\
Santa Isabel & SI 01 & 1.84 \\
Santa Isabel & SI 02 & 19.18 \\
Santa Isabel & SI 03 & 20.48 \\
Santa Isabel & SI 04 & 14.34 \\
Santa Isabel & SI 05 & 12.49 \\
Santa Isabel & SI 06 & 8.81 \\
Goiania & C 01 & 12.39 \\
Goiania & C 02 & 0.62 \\
Goiania & C 0.33 \\
\hline & & 0.13 \\
& & 0.33 \\
\hline
\end{tabular}

${ }^{\mathrm{a}}<$ Limit of quantification (LOQ)

concentration that is associated with an IQ deficit as stated by OMS in its latest publication [27], indicating potential neurotoxic effects. In contrast, the mean total mercury concentration in the hair for the control group (from the city of Goiania) was $0.36 \pm 0.25 \mathrm{mg} \mathrm{g}^{-1}$, ranging between 0.13 and $0.62 \mu \mathrm{g} \mathrm{g}^{-1}$. The participants in this group, according to the questionnaire they answered about their diets, mainly eat beef and chicken.

Vieira et al. (2013) [14], in a similar study, found an average concentration of $8.20 \mu \mathrm{g} \mathrm{g}^{-1}$ of mercury in the hair of females of the communities of the Madeira River and an average of $1.30 \mathrm{\mu g} \mathrm{g}^{-1}$ in the hair of mothers from the urban area of Porto Velho (capital of the state of Rondônia). Similarly, Dórea et al. (2013) [28] found that women, especially those living in isolated Negro River communities such as the community of Santa Isabel, who consumed fish at least once per day, presented high mercury concentrations in their hair when 
compared with women of other regions. The authors reported an average of $18.30 \mathrm{\mu g} \mathrm{g}^{-1}$ for this region, which is similar to that found in the Santa Isabel area in this study.

Faial et al. (2015) [29] evaluated mercury concentrations in the hair of 141 volunteers, residents of Barreiras in the Tapajós River region. The results showed that $84.40 \%$ of the mercury concentrations determined were higher than the concentration values associated with an IQ deficit as recommended by OMS [27]. In general, mercury contamination of the aquatic biota in the Amazon region has been widely studied because of its direct relationship with human health [28]. According to Pinheiro et al. (2012) [30], exposure to mercury in the Amazon occurs mainly in coastal communities, which are farther from urban centers. This may explain the high values found in Santa Isabel, a riverside community in the upper Negro River, where fish intake is the main source of protein. This area has a low socioeconomic background; electricity is obtained by gasoline generators and access is only possible by boat (115 km from Manaus, capital of the state of Amazon). In the control group used in this study, the average mercury concentrations were low, which is probably related to low fish consumption and work activities not linked to mining activities. According to Pirard et al. (2014) [31], fish consumption and professional activities related to mercury are the most important variables affecting mercury concentrations in hair.

The relationship between total mercury concentrations in hair and the fish consumption by lactating women in the studied communities were initially analyzed by the normality test (Shapiro-Wilk). The normality test indicated that the samples did not come from a normal population $(p<0.05)$. Based on this result, the nonparametric correlation (Spearman) was performed, as shown in Fig. 3.

The results showed that there was a low positive correlation between fish consumption and mercury concentrations in hair $(r=0.296)$, with an upward trend. However, this correlation

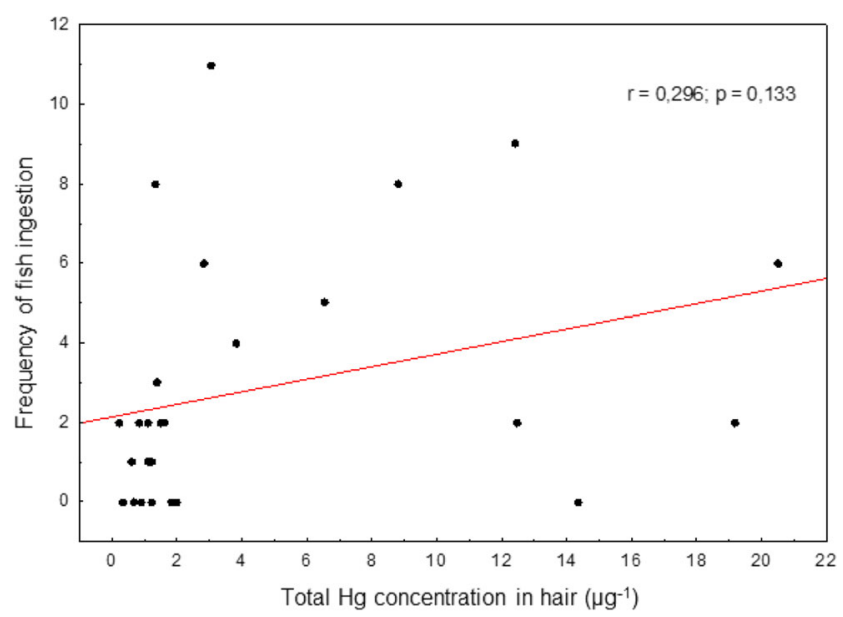

Fig. 3 Correlation between total mercury concentrations $\left(\mu \mathrm{g} \mathrm{g}^{-1}\right)$ in the hair and fish consumption of lactating women of the study communities (Madeira River, Negro River, and Goiania; Spearman, $p<0.133$ ) was not significant ( $p=0.133$ ), possibly due to the relatively small sample size in our study. Similar studies carried out in the Amazon reported that this population has one of the highest exposures to mercury in the world. This may be related to the geological formation process of the basin, where mercury is concentrated in the soil by pedogenesis, as well as to contamination from mining activities [32]. Thus, coastal communities, consuming a diet which consists mainly of fish from the rivers, are exposed to high amounts of mercury, since this element is incorporated into the tissues of aquatic organisms after methylation. Studies conducted by the same researchers in riverside communities in the Amazon region, where fish from the river is consumed almost daily, found average mercury concentrations in hair of $19.10 \mu \mathrm{g} \mathrm{g}^{-1}$ [32]. In our study, lower values were observed, except in the Santa Isabel community.

\section{Total Protein Concentration in Breast Milk}

Determination of the total protein concentration in the protein pellets obtained from the breast milk samples enabled calculation of the mass to be applied to the polyacrylamide gel, taking into account the concentration of the gel $(12.5 \% \mathrm{~m} / \mathrm{v})$. The result of these determinations indicated that the extracts obtained by solubilization of protein pellets contain $22.80 \pm 0.51 \mathrm{~g} \mathrm{~L}^{-1}$ for the lactating women of the control group (Lc), $21.70 \pm 0.38 \mathrm{~g} \mathrm{~L}^{-1}$ for the lactating women of the Madeira River (LRM), and $21.20 \pm 0.38 \mathrm{~g} \mathrm{~L}^{-1}$ for the lactating women of the Negro River (LRN).

\section{Protein Fractionation by 2D-PAGE}

Figure 4 shows examples of the gels obtained under the experimental conditions described in item 2.6. The spots in which GFAAS determinations indicated the presence of mercury are marked with circles and numbered. Table 3 shows the results of the image analysis of the gels obtained in the 2DPAGE runs.

The fractionation of the proteins of breast milk samples by 2D-PAGE, as shown in Fig. 4 and Table 3, presented a low diversity of protein spots, with average molecular weight values from 14 to $97 \mathrm{kDa}$. The images were compared between gel repetitions according to the matching made by Image Master Platinum 7.0 software, which identifies which spots are equivalent among replicates. The repetitions between the electrophoretic runs of the gels of the control sample (Lc), Madeira river (LrM), and Negro river $(\operatorname{LrN})$, shown in Table 3, presented an average correlation of 80 to $94 \%$. Matching values $\geq 80 \%$ indicate that at least $80 \%$ of the spots are present in the replicates of gels, indicating excellent repeatability and reproducibility between the 2D-PAGE runs $[22,23,25]$. Although the average number of protein spots was relatively small, protein fractionation was more efficient 
Fig. 4 Gels obtained in 2DPAGE runs of samples of breast milk of the control (a), Madeira River (b), and Negro River (c) lactating women. Experimental conditions: concentration of the gel $12.50(w / v), \mathrm{pH}$ gradient 310 , molecular mass standard 14 $97 \mathrm{kDa}$, the total run time $-10 \mathrm{~h}$
$\mathbf{A}$

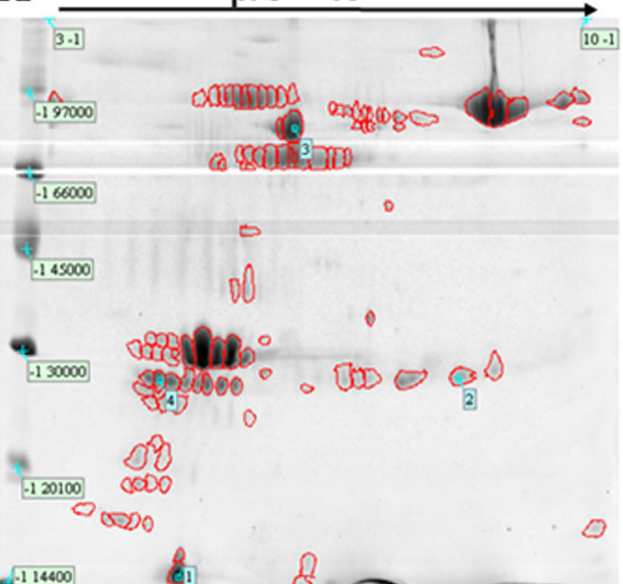

B

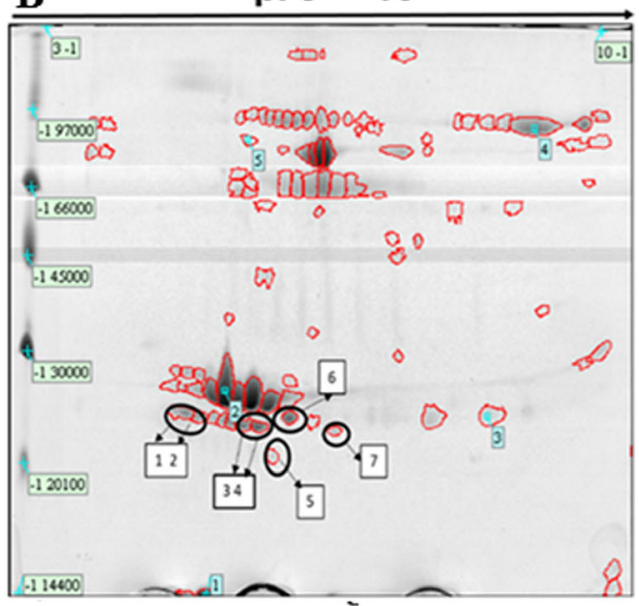

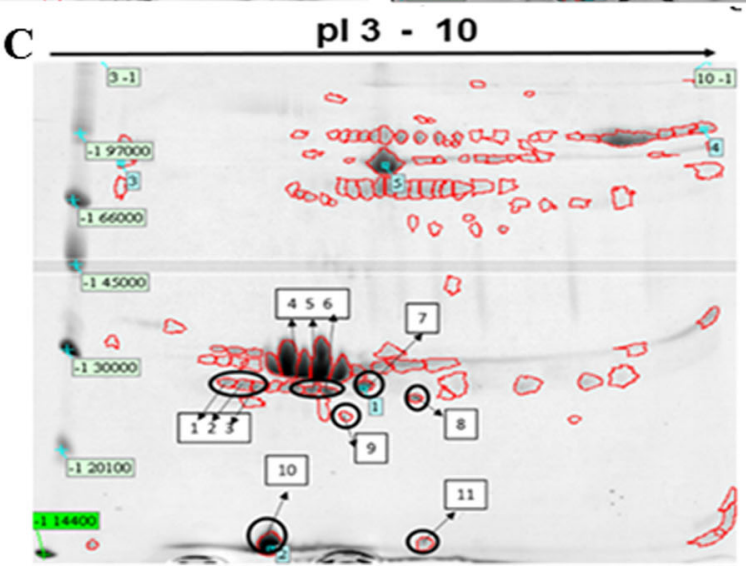

than in the results obtained by Santos et al. (2015) [18]. The breast milk proteome obtained via 2D-PAGE by these authors, also from communities on the Madeira River, showed much

Table 3 Results of image analysis with the average number of spots and correlation between repetitions $(n=3)$ of the gels of milk samples from control lactating women (Lc), lactating women of the Madeira River (LRM), and lactating women of the Negro River (LRN)

\begin{tabular}{lll}
\hline Lactating & Average number of spots & $\begin{array}{l}\text { Average correlation } \\
\text { between gels- }(\%)\end{array}$ \\
\hline Madeira River- $\mathrm{L}_{\mathrm{rM} 1}$ & $102 \pm 1.06$ & $92 \pm 1.01$ \\
Madeira River- $\mathrm{L}_{\mathrm{rM} 2}$ & $126 \pm 1.30$ & $92 \pm 1.07$ \\
Madeira River- $\mathrm{L}_{\mathrm{rM} 3}$ & $104 \pm 1.10$ & $83 \pm 1.05$ \\
Madeira River- $\mathrm{L}_{\mathrm{rM} 4}$ & $102 \pm 1.10$ & $93 \pm 1.10$ \\
Madeira River- $\mathrm{L}_{\mathrm{rM} 5}$ & $122 \pm 1.30$ & $84 \pm 1.02$ \\
Madeira River- $\mathrm{L}_{\mathrm{rM} 6}$ & $112 \pm 1.20$ & $95 \pm 1.10$ \\
Negro River- $\mathrm{L}_{\mathrm{rN} 1}$ & $122 \pm 1.30$ & $98 \pm 1.07$ \\
Negro River- $\mathrm{L}_{\mathrm{rN} 2}$ & $200 \pm 2.10$ & $98 \pm 1.10$ \\
Negro River- $\mathrm{L}_{\mathrm{rN} 3}$ & $106 \pm 1.20$ & $91 \pm 1.01$ \\
Control 1 & $111 \pm 1.20$ & $84 \pm 0.96$ \\
Control 2 & $132 \pm 1.40$ & $92 \pm 0.92$ \\
Control 3 & $114 \pm 1.20$ & \\
\hline
\end{tabular}

drag and lots of overlapping spots with matching values $<70 \%$, less than those determined in this study.

\section{Total Mercury in Samples of Breast Milk, Pellets, and Protein Spots}

The total mercury was determined in breast milk samples (fresh and lyophilized), pellets and protein spots to generate a mass balance and balance of mercury in relation to the concentration of mercury in milk samples, pellets and protein spots obtained in the fractionation process of proteins by 2D-PAGE. The limits of detection (LOD) and quantification (LOQ) of the determination method, calculated based on the standard deviation of 10 readings of the standard solution blank and on the slope of the analytical curve (LOD $=3$ /slope and $\mathrm{LOQ}=10$ /slope), were 0.017 and $0.054 \mu \mathrm{g} \mathrm{L}^{-1}$ mercury, respectively. The (LOD) and (LOQ) determined in relation to certified standard, using $0.01 \mathrm{~g}$ of DORM4 - NRC, were 0.04 and $0.10 \mu \mathrm{g} \mathrm{kg}^{-1}$, respectively [25].

Table 4 shows the total mercury concentrations of fresh and lyophilized milk samples, pellets and the certified standards Protein DORM 4 - NRC and DOLT 4 -NRC used to validate the analytical procedure. Total mercury concentrations were also carried out on fresh breast milk samples to verify if the 
Table 4 Results obtained in the determination of total mercury in breast milk samples (fresh samples and lyophilized) and protein pellets

\begin{tabular}{lllll}
\hline Lactating/certified standards & $\begin{array}{l}\text { Fresh milk } \\
\left(\mu \mathrm{g} \mathrm{L}^{-1}\right)\end{array}$ & $\begin{array}{l}\text { Lyophilized milk } \\
\left(\mu \mathrm{g} \mathrm{g}^{-1}\right)\end{array}$ & $\begin{array}{l}\text { Pellets }^{*} \\
\left(\mu \mathrm{g} \mathrm{g}^{-1}\right)\end{array}$ & $\begin{array}{l}\text { Muscle and liver } \\
\text { protein\# } \\
\left(\mu \mathrm{g} \mathrm{g}^{-1}\right)\end{array}$ \\
\hline $\mathrm{L}_{\mathrm{C} 1}$ & $<\mathrm{LOQ}^{*}$ & $<\mathrm{LOQ}^{* *}$ & $<\mathrm{LOQ}^{* *}$ & - \\
$\mathrm{L}_{\mathrm{C} 2}$ & $<\mathrm{LOQ}^{*}$ & $<\mathrm{LOQ}^{* *}$ & $<\mathrm{LOQ}^{* *}$ & - \\
$\mathrm{L}_{\mathrm{C} 3}$ & $<\mathrm{LOQ}^{*}$ & $<\mathrm{LOQ}^{* *}$ & $<\mathrm{LOQ}^{* *}$ & - \\
$\mathrm{L}_{\mathrm{rM} 2}$ & $0.25 \pm 0.003$ & $0.033 \pm 0.0004$ & $0.032 \pm 0.0003$ & - \\
$\mathrm{L}_{\mathrm{rM} 3}$ & $0.38 \pm 0.004$ & $0.054 \pm 0.0007$ & $0.047 \pm 0.0002$ & - \\
$\mathrm{L}_{\mathrm{rM} 4}$ & $0.72 \pm 0.008$ & $0.093 \pm 0.001$ & $0.079 \pm 0.0006$ & - \\
$\mathrm{L}_{\mathrm{rM} 5}$ & $0.30 \pm 0.006$ & $0.044 \pm 0.0005$ & $0.042 \pm 0.0003$ & - \\
$\mathrm{L}_{\mathrm{rM} 6}$ & $0.34 \pm 0.005$ & $0.052 \pm 0.0006$ & $0.049 \pm 0.0003$ & - \\
$\mathrm{L}_{\mathrm{rM} 7}$ & $0.74 \pm 0.009$ & $0.11 \pm 0.0016$ & $0.098 \pm 0.001$ & - \\
$\mathrm{L}_{\mathrm{rNS1}}$ & $3.30 \pm 0.04$ & $0.48 \pm 0.005$ & $0.23 \pm 0.003$ & - \\
$\mathrm{L}_{\mathrm{rNS} 2}$ & $3.70 \pm 0.04$ & $0.53 \pm 0.006$ & $0.26 \pm 0.003$ & - \\
$\mathrm{L}_{\mathrm{rNS13}}$ & $2.50 \pm 03$ & $0.37 \pm 0.004$ & $0.18 \pm 0.002$ & - \\
DORM 4-NRC & - & - & - & $0.403 \pm 0.012$ \\
DOLT 4-NRC & - & - & - & $2.53 \pm 0.07$ \\
\hline
\end{tabular}

$L_{C}$ control lactating, $L_{r M}$ Madeira River lactating, $L_{r N}$ Negro River lactating $\mathrm{LOQ}^{*}=0.054 \mu \mathrm{g} \mathrm{L}^{-1} ; \mathrm{LOQ}^{* *}=0.011 \mu \mathrm{g} \mathrm{g}^{-1}$ results were in agreement with the results of lyophilized breast milk samples. It can be seen from the results of Table 4 that the values agree. Table 5 shows the mercury concentrations obtained in the protein spots according to the procedure described in 2.7. The mercury concentrations in breast milk samples from the Negro River were measured only in lactating women 1,2, and 3 because the other lactating women did not provide sufficient sample volume to carry out the analyses. The results were validated by determination of the total mercury in certified standard proteins DORM 4-NRC and DOLT 4-NRC, as shown in Table 4. Relative standard deviation (\% RSD) values were less than $2 \%$, suggesting excellent repeatability. The total mercury concentration values found in this work (determined values $-0.403 \pm 0.007$ and $2.53 \pm 0.044 \mu \mathrm{g} \mathrm{g}^{-1}$; certified values $-0.410 \pm 0.055$ and $2.58 \pm 0.22$, respectively, for DORM4 and DOLT4) were very close to the certified values, with an absolute error of less than $2 \%$. Values with a smaller difference than $2 \%$ from the certified values prove accuracy of the method [24].

The mercury concentrations in maternal milk samples (Table 4) clearly show that the highest values were found in samples from the Negro River (range of 2.50 to $3.70 \mu \mathrm{g} \mathrm{L}^{-1}$ ), which also showed higher values of mercury in the hair samples (concentration range between 14 to $20 \mu \mathrm{g} \mathrm{g}^{-1}$ ). Samples from the Madeira River presented mercury concentration values below $0.80 \mu \mathrm{g} \mathrm{L}^{-1}$ for breast milk and below $2.00 \mu \mathrm{g} \mathrm{g}^{-1}$ for hair samples. Based on the results shown in Table 4, mass balance calculations were carried out considering the total mercury concentration of the freeze-dried milk samples and protein pellets. It was observed that in lactating women from the Madeira River communities, 85 to $97 \%$ of the mercury present in lyophilized milk can be found in the protein fraction. These results corroborate the results obtained by Santos et al. (2015) [18], who also found that approximately $96 \%$ of the total mercury in breast milk was in the protein fraction. However, these authors presented results for only a single lactating woman from the Madeira River community, while this study presents the averaged results of six women. Considering that 85 to $97 \%$ of the mercury is linked to the protein fraction, it can be inferred that 3 to $15 \%$ is bound to the lipid fraction (the fraction separated by centrifugation as described in the "Experimental" section) in organic forms, such as methylmercury $[18,23,26]$. The results obtained from lactating women from the Negro River (Table 4) reinforce this deduction. Based on mass balance calculations for the protein pellets and the freeze-dried milk samples, it was observed that approximately $49 \%$ of the total mercury is bound in the protein fraction, while the other $51 \%$ is in the lipid fraction. Several studies [33-36] have shown that due to high levels of methylation resulting from the high concentration of organic matter in the Negro River combined with low $\mathrm{pH}$ values and anoxia, much of the mercury in aquatic organisms, particularly fish, is found in the organic form (dimethyl and/or methylmercury), which can easily be absorbed by the tissues of living organisms. According to Vieira et al. (2013) [14], socioeconomic changes along the Madeira River have led to decreased fish consumption compared to that along the Negro River, where fish still constitutes an important part of the diet, which could explain the high concentrations of methylmercury and total mercury in breast milk and hair samples. Because of the long duration of breastfeeding (until approximately 30 months), children in this region absorb a substantial 
Table 5 Results of the determination of the total mercury in protein spots obtained in the protein fractionation process of the samples of breast milk of lactating women from the Madeira River and Negro River by 2DPAGE

\begin{tabular}{|c|c|c|c|}
\hline Protein spots & Molecular mass (kDa) & $\begin{array}{l}\text { Protein mass } \\
(\mu g)\end{array}$ & $\begin{array}{l}{[\mathrm{Hg}]_{\text {Total }}} \\
\left(\mathrm{ng} \mathrm{g}^{-1}\right)\end{array}$ \\
\hline $\mathrm{LrM}_{1-\text { spot2 }}$ & 23.74 & 6.90 & $24 \pm 0.30$ \\
\hline $\mathrm{LrM}_{1-s p o t 3}$ & 23.17 & 10.20 & $28 \pm 0.40$ \\
\hline $\mathrm{LrM}_{1-s p o t 4}$ & 22.73 & 10.50 & $31 \pm 0.50$ \\
\hline $\mathrm{LrM}_{1-s p o t 5}$ & 20.49 & 2.40 & $16 \pm 0.20$ \\
\hline $\mathrm{LrM}_{1-s p o t 6}$ & 23.51 & 10.60 & $43 \pm 0.50$ \\
\hline $\mathrm{LrM}_{1-s p o t 7}$ & 22.40 & 1.80 & $14 \pm 0.15$ \\
\hline $\mathrm{LrM}_{2-\text { spot } 1}$ & 27.10 & 5.60 & $28 \pm 0.80$ \\
\hline $\mathrm{LrM}_{2-s p o t 2}$ & 25.20 & 4.80 & $17 \pm 0.50$ \\
\hline $\mathrm{LrM}_{2-s p o t 3}$ & 23.70 & 3.50 & $25 \pm 0.30$ \\
\hline $\mathrm{LrM}_{2-\text { spot } 4}$ & 23.00 & 1.20 & $15 \pm 0.20$ \\
\hline $\mathrm{LrM}_{2-s p o t 5}$ & 21.50 & 12.40 & $96 \pm 2.50$ \\
\hline $\mathrm{LrM}_{2-s p o t 6}$ & 26.50 & 8.60 & $110 \pm 2.10$ \\
\hline $\mathrm{LrM}_{2-s p o t 7}$ & 22.80 & 2.40 & $13 \pm 0.20$ \\
\hline $\mathrm{LrM}_{3-s p o t 1}$ & 25.80 & 3.40 & $24 \pm 0.44$ \\
\hline $\mathrm{LrM}_{3-\text { spot2 }}$ & 25.64 & 3.96 & $28 \pm 0.50$ \\
\hline $\mathrm{LrM}_{3-s p o t 3}$ & 25.64 & 4.21 & $30 \pm 0.60$ \\
\hline $\mathrm{LrM}_{3-s p o t 4}$ & 24.84 & 3.11 & $22 \pm 0.40$ \\
\hline $\mathrm{LrM}_{3-s p o t 5}$ & 25.06 & 3.87 & $27 \pm 0.47$ \\
\hline $\mathrm{LrM}_{3-\text { spot } 6}$ & 24.72 & 4.35 & $31 \pm 0.60$ \\
\hline $\mathrm{LrM}_{3-s p o t 7}$ & 26.41 & 3.01 & $21 \pm 0.45$ \\
\hline $\mathrm{LrM}_{3-\text { spot } 8}$ & 25.93 & 7.42 & $52 \pm 0.90$ \\
\hline $\mathrm{LrM}_{3-\text { spot } 9}$ & 25.29 & 4.76 & $36 \pm 0.65$ \\
\hline $\mathrm{LrM}_{3-\text { spot } 10}$ & 25.99 & 5.61 & $40 \pm 0.73$ \\
\hline $\mathrm{LrM}_{3-\text { spot } 11}$ & 24.84 & 3.98 & $28 \pm 0.56$ \\
\hline $\mathrm{LrM}_{3-\text { spot } 12}$ & 22.57 & 1.22 & $14 \pm 0.22$ \\
\hline $\mathrm{LrM}_{4-s p o t 1}$ & 21.30 & 6.03 & $67 \pm 1.10$ \\
\hline $\mathrm{LrM}_{4-s p o t 2}$ & 20.92 & 4.70 & $76 \pm 0.93$ \\
\hline $\mathrm{LrM}_{4-s p o t 3}$ & 20.28 & 8.31 & $103 \pm 0.24$ \\
\hline $\mathrm{LrM}_{4-s p o t 4}$ & 20.01 & 1.61 & $25 \pm 0.33$ \\
\hline $\mathrm{LrM}_{4-s p o t 5}$ & 21.30 & 3.44 & $53 \pm 0.62$ \\
\hline $\mathrm{LrM}_{4-s p o t 6}$ & 19.95 & 1.60 & $25 \pm 0.44$ \\
\hline $\mathrm{LrM}_{4-s p o t 7}$ & 18.81 & 0.90 & $24 \pm 0.35$ \\
\hline $\mathrm{LrM}_{4-s p o t 8}$ & 17.99 & 0.50 & $18 \pm 0.24$ \\
\hline $\mathrm{LrM}_{5-s p o t 1}$ & 22.86 & 9.30 & $56 \pm 0.93$ \\
\hline $\mathrm{LrM}_{5-s p o t 2}$ & 22.86 & 8.50 & $39 \pm 0.96$ \\
\hline $\mathrm{LrM}_{5-s p o t 3}$ & 22.13 & 7.80 & $33 \pm 0.73$ \\
\hline $\mathrm{LrM}_{\text {5-spot } 4}$ & 21.82 & 6.74 & $38 \pm 0.71$ \\
\hline $\mathrm{LrM}_{5-s p o t 5}$ & 22.65 & 5.51 & $34 \pm 0.57$ \\
\hline $\mathrm{LrM}_{5-\text { spot } 6}$ & 21.70 & 1.14 & $24 \pm 0.34$ \\
\hline $\mathrm{LrM}_{5-s p o t 7}$ & 19.90 & 0.74 & $15 \pm 0.25$ \\
\hline $\mathrm{LrM}_{5-s p o t 8}$ & 19.70 & 0.80 & $16 \pm 0.23$ \\
\hline $\mathrm{LrM}_{6-s p o t 1}$ & 25.57 & 9.83 & $42 \pm 0.53$ \\
\hline $\mathrm{LrM}_{6-s p o t 2}$ & 25.32 & 7.26 & $32 \pm 0.43$ \\
\hline $\mathrm{LrM}_{6-s p o t 3}$ & 24.95 & 7.93 & $36 \pm 0.54$ \\
\hline $\mathrm{LrM}_{6-s p o t 4}$ & 24.95 & 6.65 & $31 \pm 0.46$ \\
\hline $\mathrm{LrM}_{6-s p o t 5}$ & 27.30 & 11.40 & $46 \pm 0.65$ \\
\hline
\end{tabular}

Table 5 (continued)

\begin{tabular}{|c|c|c|c|}
\hline Protein spots & Molecular mass (kDa) & $\begin{array}{l}\text { Protein mass } \\
(\mu \mathrm{g})\end{array}$ & $\begin{array}{l}{[\mathrm{Hg}]_{\text {Total }}} \\
\left(\mathrm{ng} \mathrm{g}^{-1}\right)\end{array}$ \\
\hline $\mathrm{LrM}_{6-s p o t 6}$ & 23.99 & 1.41 & $14 \pm 0.24$ \\
\hline $\mathrm{LrM}_{6-s p o t 7}$ & 22.07 & 0.99 & $12 \pm 0.23$ \\
\hline $\mathrm{LrM}_{6-s p o t 8}$ & 14.45 & 15.26 & $110 \pm 2.10$ \\
\hline $\mathrm{LrM}_{6-s p o t 9}$ & 14.70 & 3.15 & $26 \pm 0.36$ \\
\hline $\operatorname{LrN}_{1-\text { spot } 1}$ & 26.39 & 2.23 & $22 \pm 0.38$ \\
\hline $\mathrm{LrN}_{1-\text { spot2 }}$ & 26.03 & 4.73 & $44 \pm 0.54$ \\
\hline $\mathrm{LrN}_{1-\text { spot3 }}$ & 25.87 & 4.90 & $46 \pm 0.63$ \\
\hline $\mathrm{LrN}_{1-\text { spot } 4}$ & 25.70 & 4.34 & $41 \pm 0.55$ \\
\hline $\mathrm{LrN}_{1-\text { spot } 5}$ & 25.60 & 6.40 & $48 \pm 0.64$ \\
\hline $\mathrm{LrN}_{1-\text { spot6 }}$ & 25.33 & 8.40 & $56 \pm 0.72$ \\
\hline $\mathrm{LrN}_{1-s p o t 7}$ & 25.91 & 14.44 & $75 \pm 0.93$ \\
\hline $\mathrm{LrN}_{1-\text { spot } 8}$ & 24.64 & 3.70 & $34 \pm 0.45$ \\
\hline $\mathrm{LrN}_{1-\text { spot } 9}$ & 23.22 & 0.91 & $14 \pm 0.23$ \\
\hline $\mathrm{LrN}_{1-\text { spot } 10}$ & 14.74 & 28.63 & $210 \pm 0.37$ \\
\hline $\mathrm{LrN}_{1-s p o t 11}$ & 14.96 & 2.62 & $32 \pm 0.46$ \\
\hline $\mathrm{LrN}_{2-\text { spot } 1}$ & 25.57 & 6.86 & $410 \pm 0.57$ \\
\hline $\mathrm{LrN}_{2-s p o t 2}$ & 24.24 & 2.93 & $650 \pm 8.10$ \\
\hline $\mathrm{LrN}_{2-\text { spot3 }}$ & 18.91 & 7.08 & $240 \pm 3.42$ \\
\hline $\mathrm{LrN}_{2-\text { spot } 4}$ & 14.92 & 8.50 & $240 \pm 3.34$ \\
\hline $\mathrm{LrN}_{2-s p o t 5}$ & 15.18 & 2.31 & $510 \pm 7.21$ \\
\hline $\mathrm{LrN}_{3-\text { spot } 1}$ & 26.23 & 1.01 & $73 \pm 0.88$ \\
\hline $\mathrm{LrN}_{3-s p o t 2}$ & 25.74 & 2.32 & $160 \pm 2.30$ \\
\hline $\mathrm{LrN}_{3-\text { spot3 }}$ & 27.37 & 2.90 & $121 \pm 0.34$ \\
\hline $\mathrm{LrN}_{3-\text { spot } 4}$ & 26.60 & 6.73 & $480 \pm 6.20$ \\
\hline $\mathrm{LrN}_{3-\text { spot } 5}$ & 25.26 & 1.96 & $120 \pm 2.30$ \\
\hline $\mathrm{LrN}_{3-\text { spot6 }}$ & 25.26 & 4.21 & $260 \pm 3.25$ \\
\hline $\mathrm{LrN}_{3-s p o t 7}$ & 14.54 & 8.01 & $420 \pm 7.53$ \\
\hline
\end{tabular}

amount of mercury. However, it should be noted that soils in the Amazon are naturally high in mercury, resulting in high mercury levels of the aquatic system and, consequently, high exposure to mercury in this area [28].

The total mercury in protein spots (Table 5, Fig. 4 and Supplementary material) is on average $83-98 \%$ of the mercury present in protein pellets, as shown by the mass balance calculations that were made based on the mercury concentration present in the protein spots and in $250 \mathrm{~g}$ of the protein mass that was applied to gels. These results show that virtually all the mercury present in the protein mass applied to the fractionation process by 2D-PAGE is present in the protein spots, in which the presence of mercury was determined by GFAAS.

The protein spots that had mercury as determined by GFAAS may contain one or more proteins that exhibit characteristics of a biomarker, at the proteomic level, of toxic effects of mercury in lactating women contaminated by this element. Santos et al. (2015) [18], working with lactating 
women from the Madeira River, have determined the presence of mercury in one protein spot via GFAAS, which was then characterized by ESI-MS/MS. Based on the UniProt database, the protein spot was identified as lysozyme $\mathrm{C}$ and contained mercury linked to its structure. The authors therefore suggest using this protein as a mercury biomarker. Lysozyme $\mathrm{C}$ acts directly on bacteria and increases the activity of IgA, thus playing an important role in the defense mechanisms of newborns.

\section{Conclusions}

Two-dimensional electrophoresis (2D-PAGE) proved to be very efficient as a selectivity technique in the fractionation of proteins in breast milk samples, revealing the proteome of these samples with an average of 150 protein spots and a matching $\geq 80 \%$. Graphite furnace atomic absorption spectrometry (GFAAS), as a sensitivity technique, allowed determination of the total mercury in fresh and freeze-dried breast milk samples, pellets, and protein spots obtained in the protein fractionation process using 2D-PAGE. The results obtained from the analysis of images of 2D-PAGE electrophoresis gels and mercury mapping by GFAAS in protein spots indicate that mercury is linked to proteins with molecular weights in the range of 14-26 kDa. However, characterization of protein spots to confirm the presence of mercury is crucial to validate the toxic effects of mercury in lactating mothers.

\section{Compliance with Ethical Standards}

Funding This study was funded by Project regulated by the National Electric Energy Agency-ANEEL and developed under the Sustainable Energy R \& D Program of Brazil S.A.R \& D: 6631-0001/2012. Contract Jirau 004/13 and Brazilian research funding agencies FAPESP (Processes: 2010/51332-5 and 2013/21297-1).

Conflict of Interest The authors declare that they have no conflict of interest.

\section{References}

1. Bastos WR, Lacerda LD (2004) A CONTAMINAÇÃO POR MERCÚRIO NA BACIA DO RIO MADEIRA. Geochim Bras 18:99-114

2. Bastos WR, Rebelo MF, Fonseca MF, Almeida R, Malm O (2008) A description of mercury in fishes from the Madeira river basin, Amazon, Brazil. Acta Amazôn 38(3):431-438

3. Fadini PS, Jardim WF (2001) Is the Negro River basin (Amazon) impacted by naturally occurring mercury? Sci Total Environ 275: 71-82

4. Santos-Francés F, García-Sánchez A, Alonso-Rojo P et al (2011) Distribution and mobility of mercury in soils of a gold mining region, Cuyuni river basin, Venezuela. J Environ Manag 92: 1268-1276. doi:10.1016/j.jenvman.2010.12.003
5. Farina M, Avila DS, da Rocha JBT, Aschner M (2013) Metals, oxidative stress and neurodegeneration: a focus on iron, manganese and mercury. Neurochem Int 62:575-594. doi:10.1016/j.neuint. 2012.12.006

6. Clarkson TW, Magos L (2006) The toxicology of mercury and its chemical compounds. Crit Rev Toxicol 36:609-662. doi:10.1080/ 10408440600845619

7. Patry C, Davidson R, Lucotte M, Béliveau A (2013) Impact of forested fallows on fertility and mercury content in soils of the Tapajós River region, Brazilian Amazon. Sci Total Environ 458460:228-237. doi:10.1016/j.scitotenv.2013.04.037

8. Al-Saleh I, Abduljabbar M, Al-Rouqi R et al (2013) Mercury (Hg) exposure in breast-fed infants and their mothers and the evidence of oxidative stress. Biol Trace Elem Res 153:145-154. doi:10.1007/ s12011-013-9687-7

9. Chao H-H, Guo C-H, Huang C-B et al (2014) Arsenic, cadmium, lead, and aluminium concentrations in human milk at early stages of lactation. Pediatr Neonatol 55:127-134. doi:10.1016/j.pedneo. 2013.08.005

10. García-Esquinas E, Pérez-Gómez B, Fernández-Navarro $\mathrm{P}$ et al (2013) Lead, mercury and cadmium in umbilical cord blood and its association with parental epidemiological variables and birth factors. BMC Public Health 13:841. doi:10.1186/1471-2458-13841

11. Dorea JG, Marques RC, Isejima C (2012) Neurodevelopment of Amazonian infants: antenatal and postnatal exposure to methyland ethyl-mercury. J Biomed Biotechnol 132876:2012. doi:10. 1155/2012/132876

12. Bose-O'Reilly S, McCarty KM, Steckling N, Lettmeier B (2010) Mercury exposure and children's health. Curr Probl Pediatr Adolesc Health Care 40(8):186-215. doi:10.1016/j.cppeds.2010.07.002

13. Jedrychowski W, Jankowski J, Flak E, Skarupa A, Mroz E, Sochacka-Tatara E, Lisowska-Miszczyk I (2006) Effects of prenatal exposure to mercury on cognitive and psychomotor function in one-year-old infants: epidemiologic cohort study in Poland. Ann Epidemiol 16(6):439-447. doi:10.1016/j.annepidem.2005.06.059

14. Vieira SM, Almeida R, Holanda IBB, Mussy MH, Galvão RCF, Crispim PTB, Dorea JG, Bastos WR (2013) Total and methylmercury in hair and milk of mothers living in the city of Porto Velho and in villages along the Rio Madeira, Amazon, Brazil. Int J Hyg Environ Health 216:682-689. doi:10.1016/j.ijheh.2012.12. 011

15. García-Esquinas E et al (2011) Mercury, lead and cadmium in human milk in relation to diet, lifestyle habits and sociodemographic variables in Madrid (Spain). Chemosphere 85(2):268-276. doi:10. 1016/j.chemosphere.2011.05.029

16. Yannone SM, Hartung S, Menon AL et al (2012) Metals in biology: defining metalloproteomes. Curr Opin Biotechnol 23:89-95. doi: 10.1016/j.copbio.2011.11.005

17. García-Sevillano MÁ, García-Barrera T, Navarro-Roldán $\mathrm{F}$ et al (2014) A combination of metallomics and metabolomics studies to evaluate the effects of metal interactions in mammals. Application to Mus musculus mice under arsenic/cadmium exposure. J Proteome 104:66-79. doi:10.1016/j.jprot.2014.02.011

18. Santos FA, Cavecci B, Vieira JCS et al (2015) A metalloproteomics study on the association of mercury with breast milk in samples from lactating women in the Amazon region of Brazil. Arch Environ Contam Toxicol 69:223-229. doi:10.1007/s00244-0150161-8

19. Pozzi CMC, Braga CP, Vieira JCS et al (2015) Metal ions bound to the human milk immunoglobulin A: metalloproteomic approach. Food Chem 166:492-497. doi:10.1016/j.foodchem.2014.06.040

20. Doumas BT, Bayse DD, Borner K et al (1981) A candidate reference method for determination of total protein in serum. II Test for transferability. Clin Chem 27:1651-1654 
21. Lima PM, Neves Rde CF, dos Santos FA et al (2010) Analytical approach to the metallomic of Nile tilapia (Oreochromis niloticus) liver tissue by SRXRF and FAAS after 2D-PAGE separation: preliminary results. Talanta 82:1052-1056. doi:10.1016/j.talanta.2010. 06.023

22. dos Santos FA, Lima PM, Neves RCF et al (2011) Metallomic study on plasma samples from Nile tilapia using SR-XRF and GFAAS after separation by 2D PAGE: initial results. Microchim Acta 173: 43-49. doi:10.1007/s00604-010-0522-y

23. Braga CP, Bittarello AC, CCF P et al (2015) Mercury fractionation in dourada (Brachyplatystoma rousseauxii) of the Madeira River in Brazil using metalloproteomic strategies. Talanta 132:239-244. doi:10.1016/j.talanta.2014.09.021

24. Moraes PM, Santos FA, Cavecci B et al (2013) GFAAS determination of mercury in muscle samples of fish from Amazon, Brazil. Food Chem 141:2614-2617. doi:10.1016/j.foodchem.2013.05.008

25. Silva FA, Neves RCF, Quintero-Pinto LG et al (2007) Determination of selenium by GFAAS in slurries of fish feces to estimate the bioavailability of this micronutrient in feed used in pisciculture. Chemosphere 68:1542-1547. doi:10.1016/j. chemosphere.2007.03.003

26. Vieira JCS, Cavecci B, Queiroz JV et al (2015) Determination of the mercury fraction linked to protein of muscle and liver tissue of Tucunaré (Cichla spp.) from the Amazon region of Brazil. Arch Environ Contam Toxicol 69:422-430. doi:10.1007/s00244-0150160-9

27. Poulin J, Gibb H (2008) In: Prüss-Üstün A (ed) Mercury: assessing the environmental burden of disease at national and local levels. World Health Organization, Geneva (WHO environmental burden of disease series no. 16)

28. Dórea JG, Farina M, Rocha JBT (2013) Toxicity of ethylmercury (and thimerosal): a comparison with methylmercury. J Appl Toxicol 33(8):700-711
29. Faial K, Deus R, Deus S et al (2015) Mercury levels assessment in hair of riverside inhabitants of the Tapajós River, Pará state, Amazon, Brazil: fish consumption as a possible route of exposure. J Trace Elem Med Biol 30:66-76. doi:10.1016/j.jtemb.2014.10.009

30. Pinheiro MCN, Farripas SSM, Oikawa T, Costa CA, Amoras WW, Vieira JLF, Silveira AJA, Lima ACM, Souza GS, Silveira LCL (2012) Temporal evolution of exposure to mercury in riverside communities in the Tapajos basin, from 1994 to 2010. Bull Environ Contam Toxicol 89:119-124

31. Pirard C, Koppen G, De Cremer K et al (2014) Hair mercury and urinary cadmium levels in Belgian children and their mothers within the framework of the COPHES/DEMOCOPHES projects. Sci Total Environ 472:730-740. doi:10.1016/j.scitotenv.2013.11.028

32. Rocha AV, Cardoso BR, Cominetti C, Bueno RB, De Bortoli MC, Farias LA, Favaro DIT, Camargo LMA, Cozzolino SMF (2014) Selenium status and hair mercury levels in riverine children from Rondônia, Amazônia. Nutrition 30(11-12):1318-1323

33. Lebel J, Mergler D, Branches F et al (1998) Neurotoxic effects of low-level methylmercury contamination in the Amazonian basin. Environ Res 79:20-32. doi:10.1006/enrs.1998.3846

34. Amorim MI, Mergler D, Bahia MO et al (2000) Cytogenetic damage related to low levels of methyl mercury contamination in the Brazilian Amazon. An da Acad Bras Ciências 72:497-507

35. Bisinoti MC, Jardim WF (2004) O comportamento do metilmercúrio (metilhg) no ambiente. Quim Nov. 27(4):593-600. doi:10.1590/S0100-40422004000400014

36. Barbosa CSJ, Dórea JG, Jardim WF, Fadini PS (2004) Mercury biomagnification in a tropical black water, Rio Negro. Brazil Arch Environ Contam Toxicol 45:235-246. doi:10.1007/s00244003-0207-1 